\title{
The Yugoslav Wars as the Primordial Accumulation of Capital
}

\author{
Mirt Komel
}

If we look upon the situation of the Yugoslav Wars in the 90s, when the transition from a communist Yugoslavia with a self-managing socialist economy to a plurality of capitalistic national democracies came to being, it comes with no great surprise how the situation fits perfectly Marx's interpretation of the "primordial" or "primitive" or "previous accumulation of capital", which is violent by definition and far from being the idyllic story told by the political economists of the period. This economic fairy-tale puts the hard-working part of society that become rich on one side and the lazy that become poor on the other, and such a story was told countless times in different versions by the political economists of the period as well as those in present days who tried to analyze the war in Yugoslavia merely in terms of "economic transition" where violence is seen as an "excess" not inherent in economy as such. The main purpose of this paper is to show how the War in Yugoslavia is not an irrational excess but the other, "head" side of the same coin, that has the rational economic transition as its "cypher", and where one cannot understand one side without the other. Conceptually speaking, the purpose here is to interpret the violent dissolution of Yugoslavia and the constitution of its successor-states with a structuralist approach combining the Marxian concept of the "previous accumulation" with some of the key Lacanian psychoanalytical concepts, such as phantasm and unary trait.

\section{| The Myth of the "Previous Accumulation"}

As it is well known the basis for Marx's interpretation of the "previous accumulation of capital" was Adam Smith and his famous work The Wealth of Nations, [1] more precisely the third chapter of the second book, "Of the Accumulation of Capital or of Productive and Unpruductive Labor", where the main theoretical assertions states how the accumulation of capital must be previous to the division of labor (Smith, 1987: 142-151). The myth of the previous accumulation supposedly explains how it came that the few had accumulated wealth while the many ended up in poverty: "In times long gone by there were two sorts of people; one, the diligent, intelligent, and, above all, frugal elite; the other, lazy rascals, spending their substance, and more, in riotous living. (...) Thus it came to pass that the former sort accumulated wealth, and the latter sort had at last nothing to sell except their own skins." (Marx, 1877: 500) Like many pseudo-historical theories of the period, in a similar instance like the theories of the social contract in fact, this theory can tell us more of the standpoint of the present when it was produced then the supposed past it tries to explain.

According to Marx the "previous accumulation plays in Political Economy about the same part as original sin in theology", for "its origin is supposed to be explained when it is told as an anecdote of the past" and this "insipid childishness is every day preached to us in the defense of property" (Marx, 1877: 500). The parallel with the concept of "original sin" is very important, starting from a fact we must not forget, namely that Smith himself was not only a political economist but a moral philosopher as well. Thus, the story has its moral implication, for the "industriousness" of one group is seen as morally superior to the "laziness" of the other, this opposition coinciding with the opposition 
between "good" and "evil". But the most important aspect of this parallel between the "original sin" in Christian doctrine and the "previous accumulation" in Economic theology is that in both cases the responsibility for the current state of affairs regarding the distribution of property is transported from the present and even from history into a mythological past. The myth about one group of people that worked hard and obtained a lot and the other group that was lazy and remained with almost nothing is therefore made to justify the class-division between a minority of those who own the means of production and the majority of those who own nothing but its labor force.

A similar myth exists in the present successor-states Yugoslavia where the current distribution of property is supposed being the result of the "natural" functioning of the newly introduced "free market", which is by no means nor "natural" nor "free", to be sure: the first country to make such a step was Slovenia (to which we will come in details soon) whose first act of independence in economic terms was to close trades with the Yugoslav republics. According to this myth the historical point of the split-up of Yugoslavia functions as a "year zero" where allegedly everybody started from the same departure line, but those who embraced the new ideology worked more and subsequently become rich, while those that were lazy and remained bound to the old ideology remained behind - at least so we are told by the mainstream ideological discourse of neoliberal economics that substituted the previous one of self-managing socialism.

The functioning the myth of the "previous accumulation" in the Yugoslav situation can be clearly shown if we take a closer look at what happened in Slovenia in the "year zero", that is the year it obtained independence. After six months have passed since the referendum on independence on the 26th of December 1990, Slovenia declared sovereignty on the 25th of June 1991 and started the implementation of several independence laws and economic reforms, the introduction of democracy and the opening to foreign markets, including the introduction of its own national currency, the Slovene tolar (Cf. Pleskovic and Sachs, 1994). The then introduced Slovene macroeconomic program[2] was designed as a series of market reforms that has to be actualized together with political independence (Cf. Lipton and Sachs, 1991) - or to put it in another words: democracy was introduced in the same package with neoliberalism. The most important aspect of these economic reforms was related to the question "if the socially owned enterprises should be first renationalized and then privatized or whether the intermediate stage should be skipped. The issue was resolved in favor of direct privatization." (Cf. Pleskovic and Sachs, 1994: 211) Direct privatization meant that what was once "socially owned" according to the collective structure of ownership in the Yugoslav self-management, had now become put on the "free market" and being sold. This resulted in a fundamental change in property-structure: "At present, enterprises in Slovenia are neither state owned nor self-managed: property rights are undetermined. Managers, workers, and the state all have some de jure decision-making powers. However, in practice, most of these enterprises are controlled by managers, who have, de facto, almost absolute decision-making power over them." (Pleskovic and Sachs 1994: 210) The managers or new capitalists therefore entered the scene at the precise moment of transition, after which the once state-owned collective property diapered but was not simply become private property of all the citizens: it become "capital" in the fullest sense of the word.

In both quoted articles in the paragraph above that treats the economic aspects of the transition in Yugoslavia in general and Slovenia in particular there is, quite symptomatically by my opinion, no analyses made on the effects on the population as the result of the shift in the property-structure (and this in spite of the otherwise detailed analyses of the subject). Symptomatically absent, but not surprisingly, for all the quoted authors were advisers to Lojze Peterle, the first Prime Minister of the first Slovenian government led by the DEMOS coalition. [3] Following their discourse only one can not get any other impression that what we are dealing with is the same "insipid childishness that is every day preached to us in the defense of property" Marx spoke of, for in their discourse (and practice of the Slovenian government at the period) the transition from public to private property seems correspondent to "progress". If one wants to see the other side of the coin that was in international debates denominated the "Slovenian Success Story", one must look at least at the excellent study Social Inequality and Social Capital (cf. Dragoš and Leskošek, 2003), where the authors demonstrate how in the transition processes the common "social capital", that is the common property that was the basis of Yugoslav self-management, was damaged and almost lost through the process of denationalization and privatization, so that the general standard of living for most people in Slovenia declined in terms of social security, public services and other important aspects of living at a level of dignity proper for a living being.

The crucial point when one can nearly grasp the moment of the "previous accumulation" is precisely the denationalization and privatization process that took place and is still ongoing in a now not independent anymore member of the EU Slovenia. The self-managed companies that had a collective ownership structure were transformed 
in stock-holders owned corporations during the process of denationalization and privatization, the state being the main owner selling the companies on the stock-market to the best buyers, who are - by one way or another - part of the new Slovenian political and economical elite or "ruling class". To re-activate the parallel between the supposed secular sphere of economics and the religious realm of Christianity: "Whoever has will be given more, and he will have an abundance. Whoever does not have, even what he has will be taken from him." (Mt, 13:12) Or to put it in more common-sense words: whoever had the capital or the means to get it bought and are still buying public property and then re-selling it for more and thus achieving abundance, while whoever did not have could not buy anything and even what he had, namely a share in the public property, was and is still being taken from him through the inexorable mechanisms of the so-called "free" market.

The point of the matter is that the free-market is not "free" at all, for its installation in Slovenia and in the other successor-states of Yugoslavia with the most violent means possible demanded the highest of prices: nothing less then thousands and thousands of lives that perished during the Yugoslav Wars.

\section{Phantasmatic Narrative of the "Transition" in Yugoslavia}

The very first move Marx does with Smith's myth of the "previous accumulation" in his analyses is to historicize it in order to stress out its distinctive violent character: "In actual history it is notorious that conquest, enslavement, robbery, murder, briefly force, play the great part. In the tender annals of Political Economy, the idyllic reigns from time immemorial. Right and labor were from all time the sole means of enrichment, the present year of course always excepted. As a matter of fact, the methods of primitive accumulation are anything but idyllic." (Marx, 1877: 500) Not directly labor therefore, but violence is the source of the capital's coming to being, and in the process of dissolution of Yugoslavia we can clearly see how the constitution of the various national states and their new-born economical regimes "robbery and murder" played a greater part then any laborious activity.

The dissolution of Yugoslavia become tremendously violent soon after the other republics followed Slovenian example in declaring independence, but one must always keep in mind that this violence was not only dissolutional but also constitutional, for it was on this bases that the Yugoslav successor-states emerged. In short: violence was not only a means for the dissolution of Yugoslavia, but also - if not primary - used to constitute the new-born national states. To grasp the problem of violence during the Yugoslav war from this perspective we must now adopt Walter Benjamin's general distinction between law-keeping [rechtserhaltende] and law-giving [rechtsetzende] violence from his Critique of Violence (cf. Benjamin, 1996), or to retain the more ambivalent German original term, Gewalt, which - as Jacques Derrida interpreted Benjamin's theory - means power and violence at the same time (Derrida, 1992: 44). In this terms the war in Yugoslavia can be interpreted as a conflict between the hegemonic Yugoslav power violently usurped by the Serbian nationalists led by Slobodan Milošević on the one hand (the law-keeping Gewalt) and on the other the counter-hegemonic power and constitutional violence of the splitting Yugoslav republic becoming national states (law-giving Gewalt). Now, when it comes to state-building processes, and to clarify this blurred distinction between power and violence (a distinction that was used by Arendtians to characterize the democratic transitions in the Eastern Block in general as revolutions on the basis of popular power), we can say with Louis Althusser (1995: 105-110) that a state in order to exist - and based on our own case we can add: and also to constitute itself - needs not only the repressive apparatus (that is, direct violent force), but also an ideological one. And the main ideology that was employed in the constitutional law-giving Gewalt was the neoliberal ideology of capitalism, which promised welfare and wellbeing in the new order of things.

This is precisely the point where the myth of the "previous accumulation" repaints the violence of history with peaceful colors, segregating the violent aspect of the dissolution of Yugoslavia either in the stereotyped "irrationality of the Balkanic peoples" (and thus reproducing the classic "Balkanistic discourse"), or in the more "rational" realm of ethnocentric nationalistic politics (and thus ascribing the responsibility for violence to the "excess of nationalism"). [4] Either way the assumption is always the same, namely that the constitution of democratic and capitalistic states in general and in this region in particular is not something violent in itself and has nothing to do with the genocide in Srebrenica, the siege of Sarajevo or even the bombing of Belgrade. The myth of the "previous accumulation" tries to make a clean-cut distinction between the constitution of the new democratic states and their capitalistic economic systems promoted by statesmen and economists on one hand and on the other the massive violence waged by military and para-military armies and groups. 
Many classic as well as modern and contemporary philosophers, from Blaise Pascal to Immanuel Kant and from Walter Benjamin to Slavoj Žižek, developed a concept to grasp the moment of constitutional violence marking the beginning or coming to being of a given order. Žižek, for example, says on this point: "At the beginning of the law, there is a certain 'outlaw', a certain Real of violence which coincides with the act itself of the establishment of the reign of law: the ultimate truth about the reign of law is that of a usurpation, and all classical politico-philosophical thought rests on the disavowal of this violent act of foundation..." (Žižek, 1991: 204) The act of establishment of a given order of law is therefore outside the law itself, but there is more, for this founding and foundamental act of violence must remain concealed, for it is "the positive condition of the functioning of law: it functions insofar as its subjects are deceived, insofar as they experience the authority of law as authentic and eternal." (Žižek, 1991: 204) The structure of this concealment can be described in Lacanian terms as a phantasmatic relationship governing the relation between the subject and his trauma, or, if we broaden the case for our purposes, as the relation between a group of people and their collective trauma.[5] Again with Žižek's words: "Fantasy is the primordial form of narrative, which serves to occult some original deadlock. The sociopolitical fantasy par excellence, of course, is the myth of 'primordial accumulation': the narrative of two workers, one lazy and free-spending, the other diligent and enterprising, accumulating and investing, which provides the myth of the 'origins of capitalism', obfuscating the violence of its actual genealogy." (Žižek, 1997: 10) The trauma of the Yugoslav war was subject to such a phantasmatic narrativisation in two ways by the general public, by mainstream politics, and most importantly by scholars treating this delicate topic: on the one hand there are narratives that tries to found a causal link between the violence that accured during the Yugoslav war and the various socio-political concepts that existed before in the "Balcanistic" discourse of the West on the Balkan (the phenomena of "balkanism" reactivated) - on the other hand, more important for our task at hand, there are narratives that tries to subsume all the events into "non-violent" socio-economic terms taken from the realm of politics and economics, the governing signifier being the pacificator term "transition".

If we now look at this second type of narratives a little bit closer we can see how it perfectly fits and reproduces the myth of the "previous accumulation", for it tries to describe all the history of the Yugoslav conflict as a mere painless process of "transition" (from communism to democracy, from socialism to capitalism). What all of this "transition-narratives" have in common is a tendency to reduce the problem of violence to a very narrow sociopolitical scope that is outside the realm of "pure" economics. In fact, quite the opposite is true: the genocide in Srebrenica, the siege of Sarajevo, even the bombing of Belgrade are not moments that are foreign to, but inherent to the installation of the new order in the region we are nowadays already used to call "Western Balkans". This very term is indicative, for what happened during the Yugoslav Wars was a "westernization" of Yugoslavia, that is, the constitution of national-states with a democratic form of government and a neoliberal economic agenda.

\section{The Structure of the "Previous Accumulation" in Yugoslavia}

The main problem with our interpretation insofar is that what Marx wanted to describe while making his critique of the "previous accumulation" is the transition from feudalism to capitalism in terms of disapropriation of the workers of their means of production, a disapropriation that precedes the creation of the proletariat stricto sensu. To be sure, if we want to speak about the "proletariat" in Marxian terms it is not enough to have workers: what is needed is precisely the moment of "previous accumulation", that is, the disapropriation of the workers of their means of production and their labour force being thrown and sold on a "free market". This is a very important theoretical as well as historical problem, for at the period of our concern the workers in the self-managing Yugoslav socialism were already "proletarians".

To understand this debacle we must first understand how was Yugoslavia founded in the aftermath of the World War II. After the kingdom of Yugoslavia (1918-1941, for the first eleven years officially called "The kingdom of Serbs, Croats and Slovenes") disappeared in the ruins of the Second War the republic of Yugoslavia emerged as a result of what is known as the "Yugoslav Revolution". The Yugoslav Revolution has, as all revolutions, two main folds: one the one hand there is the element of "liberation", on the other the even more important element pf "constitution", and as Hannah Arendt pointed out, many scholars tend to forget one half of the same token in focusing just on one aspect or another:[6] "The basic misunderstanding lies in the failure to distinguish between liberation and freedom: there is nothing more futile than rebellion and liberation unless they are followed by the 
constitution of the newly won freedom." (Arendt, 2006: 133). The resistance movement led by Tito was known as People's Liberation War (NOB, "Narodnoosvobodilni boj"), and this same movement succeeded in transforming the rebellion into a revolution by founding in 1943 what after two decade of political turmoil and constitutional changes will finally become in 1963 the Socialist Federal Republic of Yugoslavia with its distinctive "Workers SelfManagement" as its fundamental basis. The point of the matter is that the revolution itself was not a proletarian revolution at all, it was a revolution made by Tito's Partisans, who were first and foremost of rural provenience. The industrialization in the full sense of the world begin only after Yugoslavia was founded, and it was during this period that the Yugoslav peasants - the once Partisans - were transformed into proletarians.

This does not mean, however, that we can situate the primordial accumulation in this period, first of all because the self-managing system presupposed that the workers owned their means of production (property was owned collectively according to the ideology of "social property"), and secondly and more importantly, there was no "freemarket" where a worker could be thrown with only his labor force to sell and live with. Therefore, if we want to trace the moment of the "previous accumulation", we must trace it precisely at the period when the Yugoslav republics split apart and founded themselves as neoliberal democracies, that is, when the socially owned property was privatized and when the workers were thrown on the free market and thus being subjected to the structural violence of the "normal" functioning of the new system.

Nonetheless, the problem we started with still persists, for the situation in Yugoslavia - and in the Eastern European countries in general for that matter - does not fit the common-sense Marxistic understanding of history as a linear succession of economic systems: slavery-feudalism-capitalism. Taking Marx's theory for a historical narrative and using it to interpret the transition in Yugoslavia in terms of "previous accumulation" therefore apparently does not hold water. Another question is if Marx himself understood his re-interpretation of Smith's theory as a historical theory. Instead of begging the question I prefer simply to base the considerations that follows on the structuralist approach to Marxism as it is understood by Louis Althusser, Étienne Balibar, et al.

From a structuralist perspective it can be stated that what is conceptualized as the "previous accumulation" by Marx does not refer to any concrete historical period: it is a theoretical tool that can help us grasp the violent moment of capitalism being installed in a given society in any given period. From here on we can re-read the beginning of the chapter of the Capital entitled The Secret of Primitive Accumulation, where it is stated that the whole movement of the capitalist mode of production lies in an apparently simple presupposition, namely that it demands the preexistence of a "primitve" or "previous" accumulation of capital: "The whole movement, therefore, seems to turn in a vicious circle, out of which we can only get by supposing a primitive accumulation (previous accumulation of Adam Smith) preceding capitalistic accumulation; an accumulation not the result of the capitalistic mode of production, but its starting point." (Marx, 1877: 500) The movement is therefore circular, "the capitalistic mode of production presupposes the capitalist mode of production" (Baechler, 1995: 169-176), and this "vicious circle" cannot be grasped as a certain universal point in history, but only as a structural moment.

If we now take into account the whole analyses made in trying to apply Marx thesis on the primordial accumulation on the example of the War in Yugoslavia, we can now see how the theory in spite of its historical inadequateness structurally fits very well into the situation during the Yugoslav War: the element of disapropriation of the worker's means of production and their being thrown on the free market, the element of violence behind this process (which is in last analyses violent in itself) and the phantasmatic "transition" discourse that tries to conceal the criminal character of the founding of capitalism in post-war Yugoslavia.

\section{| The Unary Trait of the Transition into Managerialism in Former Yugoslavia}

I will now address the problem regarding these historical and structural aspects of the transition into capitalism in the former Yugoslavia combining what was here conceptualized as a structural approach towards Marx's theory of the primordial accumulation with the Lacanian concept of "unary trait" or "unary feature", which is in its broadest meaning defines the structural moment of the raise of any given symbolic order into being.

According to Lacan's theory from the XVII. Seminar, the unary trait means the installation of a master-signifier, which is empty and void in itself but gives the meaning to the signifying chain that follows through its installation of a new symbolic order (cf. Lacan 1991). Every existing discursive regime is marked by this fundamental trait, which is not only the source of its coming to being but also keeps the symbolic order functioning and intact. For our purposes 
here it is again Žižek's $(2006,60)$ interpretation that is very useful, for he attributes to this unary trait a distinctive aspect of violence, interpreting it as symbolic violence par excellence. From this perspective every discursive space is not - as it is traditionally seen in opposition to violence - a space of egalitarian intersubjectivity, symmetrical relations and so forth, but quite the opposite, a space marked by the violence of the master-signifier installed via the unary trait. The unary trait can be therefore understood as a two-fold symbolic violence: as violence of putting a given symbolic order on feet and as violence that is thus inherent in the very core of any dominant discursive regime. Or to re-employ Benjamin's distinction: the unary tratit of the master-signifier fulfills the law-giving as well as the lawkeeping function of violence.

Already from this general theoretical sketch we can see how well the Lacanian conception of the unary trait fits what can be found in the Marxist theory of the primordial accumulation: from a structuralist approach we can identify the moment of the primordial accumulation of capital as a violent unary trait that raises the capitalistic symbolic order and its dominant discourse. The distinctive traits of the thus erected symbolic order perfectly coincides with what we already treated in dealing with Marx's interpretation of Smith's myth: there is a "primordial" structural moment of violence of the master-signifier, the effects of which are directly or indirectly violent for the subjects involved (the question of "structural" or "systemic" violence), while the dominant discourse appears as purely nonviolent and, moreover, serves to conceal any sign of violence from both: its own coming to being and its actual functioning. Or in another words: the dominant capitalistic order speaks of a "non-violent previous accumulation of capital" to canceal the violent and criminal nature of its origin, as well as it speaks in non-violent economic terms to conceal the effects of its structural violence, of the violence inherent in the "natural", "normal" functioning of the so-called free-market.

Now, to focus on the historical context in question, namely the transition in from socialism to capitalism in former Yugoslavia: in the socialistic regime the master-signifier circulating in the dominant discourse was of course "self-management" ("samoupravljanje") as the distinctive trait of the so-called "Yugoslav experiment" where the ownership was collective and property social, during the period of which any capitalistic discourse about private property and free market was banished and regarded as foreign to the existing symbolic order. At the precise moment of transition, as we have seen in the case of Slovenia, the a new master-signifier emerged, namely "management" in the western meaning of the word, for - as we have seen - "social property" ended up neither in the hands of the workers and neither at the feet of the state, but in the mouths of the new-born class of managers. Therefore, we could call this new capitalistic ideology that emerged in the ruins of former Yugoslavia as "managerialism" and its predominant discursive regime as "managerial discourse", to distinguish it from the classic conception of capitalism. This is a not at all arbitrary or cosmetic distinction, but a necessary one if we consider the historical and structural aspects of the newly born regime.

We have seen beforehand how the historical context of the rise and fall of Yugoslavia does not allow us to simply apply the theory of the primordial accumulation of capital upon any of the two transitions in question (from Kingdom of Yugoslavia to the federative republic of Yugoslavia and then to the successor-states of Yugoslavia). Moreover, considering one of the main points of the Pleskovic and Sachs (1994: 210) analyses regarding the shift in the ownership-structure in Slovenia, namely that those in control of the means of production are actually the managers, we can justify the thesis of the transition from socialism not simply to capitalism, but to managerialism. Therefore, what we are dealing with in the newly born national states in the Western Balkans is precisely a symbolic order where "management" is the master-signifier of the predominant ideological discourse of "managerialism", that is, a discourse and praxis of "effectivness" and "productivness" above any wellfare, be it the wellfare of the state or its citizens.

The Lacanian imperative of the surmoi in this situation can be best described by the inexorable alternative between "success or failure", where the managerial surmoi violently dictates: "Succeed or Perish!" And since success can be accessed only by a small minority of the population by definition, the vast majority is inexorably condemned to perish in the anonymous functioning of such a structure itself.

\section{Conclusion}

When researchers approach the problem of the dissolution of Yugoslavia and the constitution of its successorstates they usually do so in one of the two ways: they or confront the problem of the Yugoslav War in terms of 
cultural, religious or political ideologies, analyzing the various ways violence was incited, legitimized and produced, or they put the question of violence into bracelets and focus only on the formal aspects - political, legal, economical of the transition. The presupposition in the latter is that violence is something foreign to politics, law and especially economics, an "excess" that is not pertinent to the field in question. But as we have seen in applying the Marxist theory of the primordial accumulation of capital, upgraded with a Lacanian approach, to the past Yugoslav situation, violence is inherent in the very process of transition that is pacified in economic terms and concealed in the now dominant capitalistic ideology, here on the case of Slovenia specified as "managerialism".

\section{Endnotes}

1. In his interpretation in the Das Kapital Marx explicitly says that the ursprüngliche Akkumulation was not coined by himself but by Adam Smith as previous accumulation, and in fact Marx always refers to it by the term "the so-called primitive accumulation". Therefore, originally "the preivious accumulation" is not a Marxist concept, but since Marx made a critique and gave his own distinctive interpretation of the concept (the interpretation we are following here), become known and generally used in Marxist theory ever since.

2. "In the spring of 1991, the government of Slovenia designed a macroeconomic program for the economic independence and restructuring of Slovenia (Assembly of the Republic of Slovenia 1991). The program, which was subsequently passed by the Parliament, had five elements: (i) monetary independence, (ii) macroeconomic stabilization, (iii) financial restructuring of loss-making enterprises, (iv) restructuring of commercial banks, and (v) privatization. There was also a wide range of legislation undertaken to establish the basic economic institutions of a sovereign state." (Pleskovic and Sachs, 1994: 191)

3. Boris Pleskovic was the chief economic adviser to the Slovene Prime Minister Lojze Peterle in the period of economic reforms (1991-1992), while Jeffrey D. Sachs led a team of "independent" advisers (that included David Lipton) with the task of providing macroeconomic advice to Peterle and assist in the drafting and implementation of the economic reforms.

4. Actually, both can summarized into the category of "balkanism" as coined by Maria Todorova in her groundbreaking work Imagining the Balkans. The central idea is founded on Edward Said's concept of "orientalism" and lies in the assumption that there is a discourse of balkanism that creates stereotypes of the Balkans (Cf. Todorova, 1997). One of such stereotypes, actually the most spread, is that the Balkan people are "irrational and violent by nature", a stereotype that is often used common-discourse to "explain" the Yugoslav wars of the 90 s as an "excess of nationalism", as if nationalism itself is something benign and only in its "balkanic" version it turned out to be something barbarically violent.

5. A very good evaluation of the various psychoanalytic approaches to law is given by Costas Douzinas in the book The End of Human Rights, where a distinctive general point is exposed: "Psychoanalysis presents the birth of law as a crime story." (Douzinas, 2000: 298). Despite its implicite critique of the psychoanalitical approach the point is well-catched, for the history of law is a "crime story". The difference between the psychoanalitical approach and a general historical approach to the problem of constitutional violence is that psychoanalyses, at least Lacanian psychoanalyses - contrary to common opionions that people have on psychoanalyses - does not search or even try to grasp the "original story", but merely tries to conceptualize in structuralistic terms the very moment of foundation of any given symbolic order. Or, in short: the general approach of Lacanian psychoanalyses is antinarrativist, it does not tell a "crime story" nor any story, because the narrative as such - any narrative that tries to grasp the original trauma, wheter on a collective or individual level - is part of the fantasmatic relation itself that must be structurally deconstructed to its basic elements.

6. In On Revolution Hannah Arendt stress out the importance of distinguishing and at the same time keeping together this two aspects of the revolution starting from the point that many rebelions did not end with a revolution for they didn't manage to constitute a new political order and therefore do not deserve to be called a "revolutions" at all: "If however, one keeps in mind that the end of revolution is liberation, while the end of revolution is the foundation of freedom, the political scientis at least will know how to avoid the pitfall of the historian who tends to place his emphasis upon the first and violent stage of rebellion and liberation, on the uprising against tyranny, to the detriment of the quieter second stage of revolution and constitution." (Arendt, 2006: 133) 


\section{References}

Althusser, Louis. 1995. Sur la reproduction. Paris: Presses Universitaires de Paris.

Arendt, Hannah. 2006. On Revolution. New York: Penguin.

Baechler, Jean. 1995. Le capitalisme. Vol. 1: Les origins. Pariz: Folio, Gallimard.

Benjamin, Walter. 1996. Critique of Violence. In: Walter Benjamin: Selected Writings, volume 1 1913-1926. Ed. Bullock, Marcus and Jennings, Michael. Cambridge, Massachusetts and London: The Belknap Press of Harvard University Press. p. 236-53.

Douzinas, Costas. 2000. The End of Human Rights. Oxford: Hart Publishers.

Derrida, Jacques. 1992. Force of Law: The "Mystical Foundation of Authority". In: Deconstruction and the Possibility of Justice. Ed. Cornell, Drucilla, Michel Rosenfeld, Michel and Carlson, David Gray. New York and London: Routledge. p. 3-68.

Dragoš, Srečo and Leskošek, Vesna. 2003. Družbena neenakost in socialni kapital. Ljubljana: Peace Institute. Politike.

Lacan Jacques. 1991 . L'envers de la psychoanalyse. Paris: Seuil.
Lipton, David and Sachs D. Jeffrey. 1991. A program for economic sovereignty and restructuring of Slovenia. Washington D.C.: Sachs \& Associates. Mimeo.

Marx, Karl. 1887. Capital. A Critique of Political Economy. Vol. 1. The Proccess of Production of Capital. Progress Publishers, Moscow. Accesed in February 2011 at: http://www.marxists. org/archive/marx/works/1867-c1/index.htm

Pleskovic, Boris and Sachs, D. Jeffrey. 1994. Political Independence and Economic Reform in Slovenia. In: The Transition in Eastern Europe. Vol. 1. Editors/Authors: Blanchard, Oliver Jean, Froot, A. Kenneth and Sachs, D. Jeffrey. Chicago: University of Chicago Press. p.191-220.

Smith, Adam. 1987. An Inquiry Into the Nature and Causes of the Wealth of Nations. Chicago: Encyclopaedia Britannica.

Žizek, Slavoj. 1991. For They Know Not What They Do. London: Verso.

Žižek, Slavoj. 1997. The Plague of Fantasies. London: Verso.

Žižek, Slavoj. 2006. Violence. New York: Picador. 